\title{
Non-Muslim Customer Switching Behavior in Islamic Bank in Indonesia
}

\author{
HERMANITA, SUCI HAYATI \\ Faculty of Economics and Islamic Business \\ Institut Agama Islam Negeri Metro \\ Jalan Ki Hajar Dewantara No. 15A, Iringmulyo, Metro Timur, Lampung, Indonesia 34112 \\ INDONESIA
}

\begin{abstract}
The growth of Islamic banking in Indonesia has occurred significantly, one of which is in the Metro City area, Lampung Province, Indonesia. Many consumers have moved from conventional banks to Islamic banks, even this has happened to non-Muslim consumers. This study aims to describe the factors that influence the behavior of non-Muslim consumers in Metro City, Lampung Province, Indonesia, when choosing Islamic banking services over conventional banks. This is because the understanding of non-Muslim customer switching behavior is very important, especially for Islamic banking, where the application of religious principles is contained therein. This research was conducted using a mixed method with quantitative and qualitative approaches. Data collection was carried out by filling out questionnaires and interviewing 40 nonMuslim customers who became customers at Islamic Bank. Furthermore, the data were analyzed statistically using ANOVA test and Post Hoc Test to see the influence of the factors that gave the most significant influence. The results of this study indicate that the factors of price, reputation, service quality, promotion, product, location, profit, coercion, and recommendations from other customers have a significant effect on nonMuslim customers to switch to services to Islamic banks with a significance value of 0.000 at ANOVA test. Of the nine factors, recommendation factors from other customers (whether friends, relatives, or family), price, and profit are the most influencing factors.
\end{abstract}

Key-Words: - Switching Behavior Factors, Non-Muslim Customer, Islamic Bank

Received: April 12, 2021. Revised: November 17, 2021. Accepted: December 15, 2021. Published: January 11, 2022.

\section{Introduction}

Financial services are companies that are a core part of people's lives. Various types of banking companies have sprung up, both those adopting conventional and Islamic systems. Over time, Islamic banking in Indonesia has developed very rapidly with the increasing number of offices it has. Even with the innovations that have been carried out by Islamic banks, they have succeeded in generating interest from millennial category customers [1]. In addition, Islamic banks also have a good level of stability, and even have the opportunity to be more stable [2]. Based on the Financial Services Authority's report on Islamic banking statistics, it can be seen that in 2009-2015 the number of Islamic Commercial Bank offices experienced a very significant increase. Even so, it turns out that the level of effectiveness is not much different from conventional banks [3]. The number of sharia banking offices in general has increased, the number of offices in 2009 still reached 1,223 offices, however at the end of 2015 it had reached 2,881 offices.
The very rapid development of Islamic banking is also felt by people in Metro City, Lampung Province, Indonesia. There have been many Islamic financial institutions, both Sharia Banking and Baitul Mal Wat Tamwil or the Sharia Financial Services Cooperative. According to Central Bureau of Statistics data, this city has an area of $68.74 \mathrm{~km}^{2}$ which is divided into five sub-districts with a population of 155,992 people. The Muslim population in Metro City reaches 136,692 people, while the non-Muslim population is 8,629 , so the percentage of non-Muslim residents in Metro City is $5.9 \%$. The development of Islamic banking shows the positive enthusiasm of the community. One of the well-developed Islamic banks is Bank Syariah Mandiri. Bank Syariah Mandiri is a sharia commercial bank that has changed its function from a conventional bank to a sharia bank. Bank Syariah Mandiri was founded in 1999. Meanwhile, in Metro City, Lampung Province, Indonesia, Bank Syariah Mandiri was established on October 24, 2005, which is located in the center of Metro city. Bank 
Syariah Mandiri besides having Muslim customers also has quite a lot of non-Muslim customers [4].

An interesting thing to note is when we find the many phenomena of non-Muslim people who have switched banking services from conventional to Islamic banks (switching behavior). In fact, services at this bank are carried out based on Islamic concepts. So that there are differences in religious principles in the process. The phenomenon of the movement of non-Muslim customers to Islamic banking services is something that needs to be studied in depth. The research was conducted to examine in depth the factors that influence the behavior of shifting consumers from conventional bank services to Islamic banks. Based on the above, the results of this study can be used as a description of information for Islamic banking in the development process, especially in terms of attracting prospective non-Muslim customers. So that Islamic banking has information related to things that need to be more focused on developing more effective and efficient services.

\section{Literature Review}

\subsection{Islamic Banking}

Islamic banking is a banking system which in practice is based on Islamic law (sharia) $[5,6]$. The implementation of Islamic Bank operational activities is based on the guidance of the Qur'an and Hadith [6]. The formation of this system was based on the prohibition in Islam to lend or collect loans by charging interest on loans (usury), as well as the prohibition to invest in prohibited businesses (haram) [7]. The prohibition is also in line with the theory and concept of maqashid sharia which recommends Muslims to maintain the 5 components in order to create the benefit of the ummah and prevent harm, namely: safeguarding faith (din), soul (nafs), reason (aql), descent (nasl) and property (maal).

\subsection{Switching Behavior}

Switching behavior is the process of moving consumers, both individuals and groups, from service providers that are currently being used to new service providers $[8,9,10,11,12]$. An understanding of switching behavior is very important for banking companies to understand people's behavior to protect customers [13]. This is because the loss of customers will have a negative impact, such as the need for additional costs to find new customers, loss of future investment, and can even damage the company's reputation and image [14]. Reputation, described as social identity, is an important intangible resource and can make a significant contribution to the performance and survival of the company. An indication of the success of building a reputation can be achieved if the company has good character in providing products or services $[15,16]$. In general, switching behavior occurs due to customer disappointment with a product or finding another product that is better. For companies, understanding consumers will be the key to being able to compete better [17, 18]. There are many factors that motivate consumers to switch, including 1) price considerations; 2) reputation; 3) quality of service; 4) promotion; 5) products; 6) location; 7) profit; 8) there is coercion; and 9) recommendations from other customers [9, $19,20,21,22,23,24,25]$. Changes in customer behavior are also influenced by social, cultural, personal, and psychological factors that become their considerations for transferring bank services $[17,26]$.

\subsection{Previous Research}

Clemes, Gan, and Zheng [9] analyzed the factors that influence customer switching behavior (price, response, service quality, customer commitment, service products, satisfaction, effective advertising, and involunatary switching) of banking customers in New Zealand. The results of this research state that factors such as customer commitment, service quality, reputation, and customer satisfaction are the main factors that influence customer behavior in switching banks. Several studies have stated that price is the dominant factor in determining switching behavior by customers [19, 27, 28]. Research conducted by Colgate and Hedge [27] for the banking industry in Australia and New Zealand states that price is the first determining factor for customers in determining switching behavior to other banks. Then another research conducted by Subramaniam and Ramachandran [28] on Customer Switching Behavior in Banking Industry shows price and reputation factors as the main factors that significantly influence customer switching behavior in Malaysia.

\section{Methods}

This research uses mixed methods with quantitative and qualitative data analysis. The use of qualitative data processing is carried out to understand the phenomenon as a whole [29]. In addition, this study uses a phenomenological approach to understand 
and reveal emerging phenomena [30, 31]. The data collected in this study is primary data which is directly obtained from non-Muslim customers at Bank Syariah Mandiri branch of Metro City, Lampung Province, Indonesia.

\subsection{Sample}

Samples were taken using purposive sampling technique. Purposive sampling is a sampling technique based on certain criteria [32]. The criteria that must be met in order to be sampled are nonMuslim customers who have a sharia bank account at the Metro City branch of Bank Syariah Mandiri, Lampung Province, Indonesia. The number of samples involved was 40 people.

\subsection{Data Collection Techniques and Data Analysis}

Data was collected through filling out questionnaires and interviews with non-Muslim customers. The questionnaire contains questions related to nine factors that influence theoretical switching behavior. These factors are 1) price considerations; 2) reputation; 3) quality of service; 4) promotion; 5) products; 6) location; 7) profit; 8) there is coercion; and 9) recommendations from other customers. The questionnaire used was tested for validity and reliability first to see its feasibility. The validity of the instrument is done by measuring the value of its contents which involves the assessment of seven experts. While the reliability of the instrument was done by measuring the Alpha Cronbach value.

The data obtained through filling out questionnaires by participants were analyzed statistically using the ANOVA test. However, as a condition for the ANOVA test, the data obtained must be tested for normality and homogeneity first. If the data are normal and homogeneous, the ANOVA test can be performed. In addition, to deepen the information obtained through statistical analysis, qualitative data analysis is necessary. This is done based on the data collected through interview sessions and used to confirm the quantitative data.

\section{Results and Discussion}

\subsection{Instrument Validity}

Samples were taken using purposive sampling technique. Purposive sampling is a sampling technique based on certain criteria [32]. The criteria that must be met in order to be sampled are nonMuslim customers who have a sharia bank account at the Metro City branch of Bank Syariah Mandiri, Lampung Province, Indonesia. The number of samples involved was 40 people.

The instrument validity test was carried out based on the assessment by seven experts through filling out a questionnaire (content validity). The data of validity test results can be seen in Table 1 .

Table 1. Results of the Research Questionnaire Validity Test

\begin{tabular}{|c|c|c|}
\hline & & Value \\
\hline \multirow[t]{4}{*}{ Price consideration aspect } & $\mathrm{N}$ & 11 \\
\hline & Critical CVR & 0,622 \\
\hline & CVR minimum & 0,714 \\
\hline & CVR maximum & 1 \\
\hline \multirow[t]{4}{*}{ Reputation aspect } & $\mathrm{N}$ & 8 \\
\hline & Critical CVR & 0,622 \\
\hline & CVR minimum & 0,857 \\
\hline & CVR maximum & 1 \\
\hline \multirow[t]{4}{*}{ Service quality aspect } & $\mathrm{N}$ & 9 \\
\hline & Critical CVR & 0,622 \\
\hline & CVR minimum & 0,857 \\
\hline & CVR maximum & 1 \\
\hline \multirow[t]{4}{*}{ Promotion aspect } & $\mathrm{N}$ & 6 \\
\hline & Critical CVR & 0,622 \\
\hline & CVR minimum & 0,714 \\
\hline & CVR maximum & 1 \\
\hline \multirow[t]{4}{*}{ Product aspect } & $\mathrm{N}$ & 11 \\
\hline & Critical CVR & 0,622 \\
\hline & CVR minimum & 0,714 \\
\hline & CVR maximum & 1 \\
\hline \multirow[t]{4}{*}{ Location aspect } & $\mathrm{N}$ & 6 \\
\hline & Critical CVR & 0,622 \\
\hline & CVR minimum & 0,857 \\
\hline & CVR maximum & 1 \\
\hline \multirow[t]{4}{*}{ Profit aspect } & $\mathrm{N}$ & 7 \\
\hline & Critical CVR & 0,622 \\
\hline & CVR minimum & 0,714 \\
\hline & CVR maximum & 1 \\
\hline \multirow[t]{4}{*}{ Coercion aspect } & $\mathrm{N}$ & 6 \\
\hline & Critical CVR & 0,622 \\
\hline & CVR minimum & 0,714 \\
\hline & CVR maximum & 1 \\
\hline \multirow{4}{*}{$\begin{array}{l}\text { Aspect of recommendations from } \\
\text { other customers }\end{array}$} & $\mathrm{N}$ & 8 \\
\hline & Critical CVR & 0,622 \\
\hline & CVR minimum & 0,857 \\
\hline & CVR maximum & 1 \\
\hline
\end{tabular}

Based on the data in Table 1, it can be seen that the critical CVR value is 0.622 . This value is a critical CVR value if it involves seven experts in the questionnaire assessment (Lawshe, 1975). If the CVR value of the questionnaire is above the critical CVR value, it can be said that the instrument has good validity as a measuring instrument. If you look at the data in Table 1, the minimum CVR value for price consideration aspect is 0.714 , reputation aspect is 0.857 , service quality aspect is 0.857 , Promotion aspect is 0.714 , product aspect is 0.714 , location aspect is 0.714 , profit aspect is 0.714 , coercion 
aspect of 0.714 , and aspect of recommendations from other customers of 0.857 . The overall minimum CVR value in each of these aspects is above the critical CVR value. This shows that each question item in the instrument has a good level of validity. Of course this is very important because a questionnaire that has a good level of validity will be able to measure what it wants to measure [33, 34]. This means that the prepared questionnaire can be used and has good measurement accuracy.

\subsection{Data Collection Techniques and Data Analysis}

The reliability value is related to the reliability of the questionnaire when it is used to measure the same thing [35]. Measurement of the reliability of the designed questionnaire was carried out by measuring the value of the Cronbach Aplha. Reliability test results data can be seen in Table 2 .

Table 2. Questionnaire Reliability Test Results

\begin{tabular}{|l|c|}
\hline \multicolumn{1}{|c|}{ Factor } & $\begin{array}{c}\text { Cronbach's } \\
\text { Alpha }\end{array}$ \\
\hline $\begin{array}{l}\text { Questions about price consideration } \\
\text { aspect }\end{array}$ & 0,933 \\
\hline Questions about reputation aspect & 0,972 \\
\hline Questions about service quality aspect & 0,953 \\
\hline Questions about promotion aspect & 0,914 \\
\hline Questions about product aspect & 0,928 \\
\hline Questions about location aspect & 0,911 \\
\hline Questions about profit aspect & 0,939 \\
\hline Questions about coercion aspect & 0,941 \\
\hline $\begin{array}{l}\text { Questions about aspect of } \\
\text { recommendations from other } \\
\text { customers }\end{array}$ & 0,927 \\
\hline
\end{tabular}

Based on the data in Table 2, the Cronbach's Alpha value of all aspects of the question is above 0.9. According to Firman [35], this value is in the very high reliability category. Of course this is related to the consistency of the instrument in describing the information obtained [34, 35]. Based on this, it can be said that the designed questionnaire can be used for data collection tools in this study

\subsection{Analysis of Factors Affecting Switching Behavior}

Before analyzing the factors that affect the switching behavior, it is necessary to test the normality and homogeneity of the data. The normality and homogeneity tests were carried out using the SPSS program. The results of the analysis showed that the data were normally distributed and homogeneous with a significance value of more than 0.05 (Sig. > 0.05). Where is the Sig. for homogeneity and normality tests were 0.325 and 0.062 , respectively. When the Sig. is above the $\alpha$ value (0.05), then the data is included in the normal and homogeneous category [32].

Because the data are normal and homogeneous, the ANOVA test can be carried out to analyze the influence of price, reputation, service quality, promotion, product, location, profit, coercion, and recommendations from other customers on the phenomenon of switching behavior. Statistical analysis data can be seen in Table 3.

Table 3. Results of Statistical Analysis on Factors Affecting Switching Behavior

\begin{tabular}{|l|c|c|c|c|c|}
\hline & $\begin{array}{c}\text { Sum of } \\
\text { Squares }\end{array}$ & df & $\begin{array}{c}\text { Mean } \\
\text { Square }\end{array}$ & F & Sig. \\
\hline $\begin{array}{l}\text { Between } \\
\text { Groups }\end{array}$ & 608.439 & 8 & 76.055 & 5.342 & .000 \\
\hline Within Groups & 4997.425 & 351 & 14.238 & & \\
\hline Total & 5605.864 & 359 & & & \\
\hline
\end{tabular}

The data in Table 3 shows the Sig. value amounting to 0,000 . This value is below the $\alpha$ value, namely 0.05 . It can be said that all factors have a significant effect on the switching behavior. This result is in accordance with the statement that there are several factors behind the consumer switching, namely 1) price considerations; 2) reputation; 3) quality of service; 4) promotion; 5) products; 6) location; 7) profit; 8) coercion; and 9) recommendations from other customers $[9,19,20$, $21,22,25,36]$. The results of the interview also show that in general all customers take these nine factors into consideration in choosing Islamic banking services over conventional banks.

To see which factors have the most influence, further statistical analysis is needed. Post hoc analysis is required to provide this information. The results of the Post Hoc Test in Table 4 provide information that in fact, of the nine factors, the recommendation factor from other customers is the factor that most influences the switching behavior. This can be seen from the significance value of other factors which are below 0.05 . When the significance value is below the $\alpha$ value (0.05), it can be said that this aspect has a significant influence [30]. Digging deeper information is needed to confirm these data by conducting interviews with participants. The results of the interview provide an illustration that it turns out that they moved to Islamic banks because of invitations from friends, relatives, and even family who had already become customers of Islamic banks. They actually do not know much about the Islamic banking system, even though they know that Islamic banks are banks specifically for Muslims. However, other information has also been obtained, where the information they get from other customers is related 
Table 4. Post Hoc Analysis Results About Factors Affecting Switching Behavior

\begin{tabular}{|c|c|c|c|c|c|c|}
\hline \multirow{2}{*}{ (I) Factor } & \multirow{2}{*}{ (J) Factor } & \multirow{2}{*}{$\begin{array}{c}\text { Mean } \\
\text { Difference (I-J) }\end{array}$} & \multirow{2}{*}{ Std. Error } & \multirow{2}{*}{ Sig. } & \multicolumn{2}{|c|}{ 95\% Confidence Interval } \\
\hline & & & & & Lower Bound & Upper Bound \\
\hline \multirow{8}{*}{ Price } & Reputation & .77500 & .84373 & .992 & -1.8585 & 3.4085 \\
\hline & Quality of Service & 1.40000 & .84373 & .771 & -1.2335 & 4.0335 \\
\hline & Promotion & 1.12500 & .84373 & .921 & -1.5085 & 3.7585 \\
\hline & Product & 1.52500 & .84373 & .677 & -1.1085 & 4.1585 \\
\hline & Location & 1.55000 & .84373 & .657 & -1.0835 & 4.1835 \\
\hline & Profit & 1.90000 & .84373 & .375 & -.7335 & 4.5335 \\
\hline & Coercion & .55000 & .84373 & .999 & -2.0835 & 3.1835 \\
\hline & Other Customer Recommendations & $4.85000^{*}$ & .84373 & .000 & 2.2165 & 7.4835 \\
\hline \multirow{8}{*}{ Reputation } & Price & -.77500 & .84373 & .992 & -3.4085 & 1.8585 \\
\hline & Quality of Service & .62500 & .84373 & .998 & -2.0085 & 3.2585 \\
\hline & Promotion & .35000 & .84373 & 1.000 & -2.2835 & 2.9835 \\
\hline & Product & .75000 & .84373 & .993 & -1.8835 & 3.3835 \\
\hline & Location & .77500 & .84373 & .992 & -1.8585 & 3.4085 \\
\hline & Profit & 1.12500 & .84373 & .921 & -1.5085 & 3.7585 \\
\hline & Coercion & -.22500 & .84373 & 1.000 & -2.8585 & 2.4085 \\
\hline & Other Customer Recommendations & $4.07500^{*}$ & .84373 & .000 & 1.4415 & 6.7085 \\
\hline \multirow{8}{*}{ Quality of Service } & Price & -1.40000 & .84373 & .771 & -4.0335 & 1.2335 \\
\hline & Reputation & -.62500 & .84373 & .998 & -3.2585 & 2.0085 \\
\hline & Promotion & -.27500 & .84373 & 1.000 & -2.9085 & 2.3585 \\
\hline & Product & .12500 & .84373 & 1.000 & -2.5085 & 2.7585 \\
\hline & Location & .15000 & .84373 & 1.000 & -2.4835 & 2.7835 \\
\hline & Profit & .50000 & .84373 & 1.000 & -2.1335 & 3.1335 \\
\hline & Coercion & -.85000 & .84373 & .985 & -3.4835 & 1.7835 \\
\hline & Other Customer Recommendations & $3.45000^{*}$ & .84373 & .002 & .8165 & 6.0835 \\
\hline \multirow{8}{*}{ Promotion } & Price & -1.12500 & .84373 & .921 & -3.7585 & 1.5085 \\
\hline & Reputation & -.35000 & .84373 & 1.000 & -2.9835 & 2.2835 \\
\hline & Quality of Service & .27500 & .84373 & 1.000 & -2.3585 & 2.9085 \\
\hline & Product & .40000 & .84373 & 1.000 & -2.2335 & 3.0335 \\
\hline & Location & .42500 & .84373 & 1.000 & -2.2085 & 3.0585 \\
\hline & Profit & .77500 & .84373 & .992 & -1.8585 & 3.4085 \\
\hline & Coercion & -.57500 & .84373 & .999 & -3.2085 & 2.0585 \\
\hline & Other Customer Recommendations & $3.72500^{*}$ & .84373 & .000 & 1.0915 & 6.3585 \\
\hline \multirow{8}{*}{ Product } & Price & -1.52500 & .84373 & .677 & -4.1585 & 1.1085 \\
\hline & Reputation & -.75000 & .84373 & .993 & -3.3835 & 1.8835 \\
\hline & Quality of Service & -.12500 & .84373 & 1.000 & -2.7585 & 2.5085 \\
\hline & Promotion & -.40000 & .84373 & 1.000 & -3.0335 & 2.2335 \\
\hline & Location & .02500 & .84373 & 1.000 & -2.6085 & 2.6585 \\
\hline & Profit & .37500 & .84373 & 1.000 & -2.2585 & 3.0085 \\
\hline & Coercion & -.97500 & .84373 & .965 & -3.6085 & 1.6585 \\
\hline & Other Customer Recommendations & $3.32500^{*}$ & .84373 & .003 & .6915 & 5.9585 \\
\hline & Price & -1.55000 & .84373 & .657 & -4.1835 & 1.0835 \\
\hline & Reputation & -.77500 & .84373 & .992 & -3.4085 & 1.8585 \\
\hline & Quality of Service & -.15000 & .84373 & 1.000 & -2.7835 & 2.4835 \\
\hline & Promotion & -.42500 & .84373 & 1.000 & -3.0585 & 2.2085 \\
\hline Location & Product & -.02500 & .84373 & 1.000 & -2.6585 & 2.6085 \\
\hline & Profit & .35000 & .84373 & 1.000 & -2.2835 & 2.9835 \\
\hline & Coercion & -1.00000 & .84373 & .959 & -3.6335 & 1.6335 \\
\hline & Other Customer Recommendations & $3.30000^{*}$ & .84373 & .003 & .6665 & 5.9335 \\
\hline & Price & -1.90000 & .84373 & .375 & -4.5335 & .7335 \\
\hline & Reputation & -1.12500 & .84373 & .921 & -3.7585 & 1.5085 \\
\hline & Quality of Service & -.50000 & .84373 & 1.000 & -3.1335 & 2.1335 \\
\hline & Promotion & -.77500 & .84373 & .992 & -3.4085 & 1.8585 \\
\hline Profit & Product & -.37500 & .84373 & 1.000 & -3.0085 & 2.2585 \\
\hline & Location & -.35000 & .84373 & 1.000 & -2.9835 & 2.2835 \\
\hline & Coercion & -1.35000 & .84373 & .804 & -3.9835 & 1.2835 \\
\hline & Other Customer Recommendations & $2.95000^{*}$ & .84373 & .015 & .3165 & 5.5835 \\
\hline & Price & -.55000 & .84373 & .999 & -3.1835 & 2.0835 \\
\hline & Reputation & .22500 & .84373 & 1.000 & -2.4085 & 2.8585 \\
\hline & Quality of Service & .85000 & .84373 & .985 & -1.7835 & 3.4835 \\
\hline Coercion & Promotion & .57500 & .84373 & .999 & -2.0585 & 3.2085 \\
\hline Coercion & Product & .97500 & .84373 & .965 & -1.6585 & 3.6085 \\
\hline & Location & 1.00000 & .84373 & .959 & -1.6335 & 3.6335 \\
\hline & Profit & 1.35000 & .84373 & .804 & -1.2835 & 3.9835 \\
\hline & Other Customer Recommendations & $4.30000^{*}$ & .84373 & .000 & 1.6665 & 6.9335 \\
\hline & Price & $-4.85000^{*}$ & .84373 & .000 & -7.4835 & -2.2165 \\
\hline $\begin{array}{l}\text { Other Customer } \\
\text { Remmendations }\end{array}$ & Reputation & $-4.07500^{*}$ & .84373 & .000 & -6.7085 & -1.4415 \\
\hline Recommendations & Quality of Service & $-3.45000^{*}$ & .84373 & .002 & -6.0835 & -.8165 \\
\hline
\end{tabular}




\begin{tabular}{|l|l|l|l|l|l|c|}
\hline & Promotion & $-3.72500^{*}$ & .84373 & .000 & -6.3585 & -1.0915 \\
\cline { 2 - 7 } & Product & $-3.32500^{*}$ & .84373 & .003 & -5.9585 & -.6915 \\
\cline { 2 - 7 } & Location & $-3.30000^{*}$ & .84373 & .003 & -5.9335 & -.6665 \\
\cline { 2 - 7 } & Profit & $-2.95000^{*}$ & .84373 & .015 & -5.5835 & -.3165 \\
\cline { 2 - 8 } & Coercion & $-4.30000^{*}$ & .84373 & .000 & -6.9335 & -1.6665 \\
\hline
\end{tabular}

*. The mean difference is significant at the 0.05 level.

to price, product, service quality and profit. They get detailed information about these four things from friends, colleagues, and family. This means, indirectly, these other factors become the determinants for them to choose Islamic banks over conventional banks.

Of the four factors, price and profit are the most influencing factors. This is because the price factor will affect consumer attitudes because prices include various costs, both those obtained by the customer and those that must be incurred by the customer [37]. It is known that the administrative fees for Islamic bank services are indeed cheaper than conventional banks, there are even certain products that do not apply service administration fees. Apart from the absence of a monthly discount so that money is not reduced, another consideration is related to the minimum balance set by Islamic banks. Of course this will be a consideration for consumers because it relates to expenses and income.

From the explanations expressed by the participants, it can be understood that another consideration for non-Muslim customers to become customers of Islamic banks is their interest in implementing profit-sharing products in Islamic banks. From profit sharing products, non-Muslim customers feel more profitable than conventional systems and hope that the future will be even better. This is because the profit sharing system is highly dependent on the performance and development of the bank. If the bank's performance continues to increase, the amount of profit sharing will increase. In contrast to the interest system at conventional banks, which remain flat even though the economy is growing well. This is also in accordance with the statement put forward by Keaveney and Parthasarathy [12] that apart from the reasons stated above, the things that attract non-Muslim customers and switch to Islamic banks are the benefits obtained by non-Muslim customers.

Based on the results of quantitative and qualitative data mining, in fact non-Muslim customers can enjoy the benefits of the Islamic banking system. This does not only apply in Indonesia, but in various other countries that have sharia banking services. This is because basically the system that is run in Islamic banks is the same, namely based on Islamic law. The superior services provided by Islamic banks allow it to support its rapid development. Marketing strategies need to be continuously improved, such as the ease of borrowing funds, but still going through the predictive analysis approval stage [38]. However, bank managers must be ready to manage human resources so that bank operations will be effective and efficient [39].

\section{Conclusion}

Switching behavior to Islamic banks by non-Muslim customers is not based on religious differences. The phenomenon of moving non-Muslim customers to Islamic banks is very much influenced by the information submitted by other customers, such as friends, relatives, or family. In addition, the price and profit factors that are considered more favorable are also considered by non-Muslim customers. From these results, Islamic banking companies can have an overview of the characteristics of the switching behavior of non-Muslim customers. The influence of the invitation information factor from people who have become customers of Islamic banks to other people, especially non-Muslims, is indirectly related to service quality, price, and benefits based on their experience. Of course this needs to be a consideration for the company that in essence maximum service will have a tremendous impact on the company's development, in addition to the influence of the price and profit factors.

In addition, the results of this study can also provide information that Islamic banks whose work system is based on Islamic law do not limit themselves to non-Muslim customers. This means that non-Muslim customers can also take advantage of the advantages of the Islamic banking system to maximize profits, such as the absence of monthly administration fees or a profit-sharing system that allows a higher amount of profit.

\section{References:}

[1] Bakry, M., et al., How to Attract Millennials? Indonesian Sharia Banking Opportunities, WSEAS TRANSACTIONS on BUSINESS and ECONOMICS, Vol. 18, 2021, pp. 376-385.

[2] Zahra, S.F., Murdayanti, Y., and Amal, M.I., Sharia Banking Stability Against Macroeconomic Shocks: A Comparative 
Analysis in the ASEAN Region, Journal of Asian Finance, Economics and Business, Vol. 8, No. 4, 2021, pp. 151-159. https://doi.org/ 10.13106/jafeb.2021.vol8.no4.0151

[3] Yusuf, A.A, Santi, N., and Rismaya, E., The Efficiency of Islamic Banks: Empirical Evidence from Indonesia, Journal of Asian Finance, Economics and Business, Vol. 8, No. 4, 2021, pp. 0239-0247. https://doi.org/ 10.13106/jafeb.2021.vo18.no4.0239

[4] Susanto, H., General Support Staff, Interview. Metro, March 3, 2017.

[5] Muslimin, U.R., Habbe, A.H., and Tawakkal, Religiosity, Religiosity Gap, and Sharia Bank Customer Switching Behavior, Universitas Hasanuddin : Fakultas Ekonomi dan Bisnis, 2017.

[6] Wahyudi, et al., Capital Adequacy Ratio, Profit-Sharing and Return On Asset: Case Study of Indonesian Sharia Banks, WSEAS TRANSACTIONS on BUSINESS and ECONOMICS, Vol. 16, 2019, pp. 138-144.

[7] Barus, E.E. and Soemitra, A., Islamic Fintech Collaboration: Indonesia's Economic Readiness Towards A New Normal Era, Proceeding International Seminar on Islamic Studies, Vol. 2, No. 1, 2021, pp. 543-554. http://jurnal. umsu.ac.id/index.php/insis/article/download/58 59/pdf_198

[8] Nyame, R.K. and Nimako S.G., Influence of Demography, Religiosity and Porting Behaviour on Switching Behaviour of Mobile Subscribers: Evidence from A Developing Country, International Journal of Business and Management, Vol. 10, No. 7, 2015. https://doi.org/10.5539/ ijbm.v10n7p158

[9] Clemes, et al., Costumer Switching Behavior in The New Zealand Banking Industry, Banks and Bank Systems, Vol. 2, No. 4, 2007, pp. 50 - 65. https://businessperspectives.org/images/pdf /applications/publishing/templates/article/assets /2007/BBS en 2007 4_Clemes.pdf

[10] Mangkunegara, A.P., Consumer Behavior, Bandung: PT Rafika Aditama, 2002.

[11] Louis, W.R., Taylor, D.M. and Neil, T., Costbenefit analyses for your group and yourself: The rationality of decision-making in conflict, International Journal of Conflict Management, Vol. 15, No. 2, 2004, pp. 110-143. https://doi.org/10.1108/eb022909

[12] Keaveney, S.M., \& Parthasarathy, M., Customer switching behavior in online services: an exploratory study of the role of selected attitudinal, behavioral, and demographic factors, Journal of the Academy of Marketing Science, Vol. 29, No. 4, 2001, pp. 374-390. https://doi.org/10.1177/03079450094 $\underline{225}$

[13] Nimako, S.G., Consumer Switching Behaviour: A Theoretical Reviewand Research Agenda, Research Journal of Social Science \& Management, Vol. 02, No. 03, 2012. https://citeseerx.ist.psu.edu/viewdoc/download? doi $=10.1 .1 .868 .4373 \&$ rep $=$ rep1\&type $=$ pdf

[14] Roos, I., Edvardsson, B. and Gustafsson, A., Customer, Switching Patterns in Competitive and Noncompetitive Service Industries, Journal of Service Research, Vol. 6, No. 256, 2004, pp. 256-271. https://doi.org/10.1177\%2F10946705 $\underline{03255850}$

[15] Suranto, B. \& Rismiati E.C., Marketing of Goods and Services, Yogyakarta: Kanisius, 2001.

[16] Anderson, G.Jnr., Religion and Morality in Ghana: A Reflection, Global Journal of Arts Humanities and Social Sciences, Vol. 1, No. 3, 2013, pp. 162-170. https://www.eajournals.org/ wp-content/uploads/Religion-and-Morality-inGhana.pdf

[17] Kotler, P., Marketing (Jilid I), Jakarta: Erlangga, 1999.

[18] Ihalauw, J.I.O.I. \& Prasetijo, R., Consumer Behavior, Salatiga: Penerbit Andi, 2004.

[19] Keaveney, S.M., Customer Switching Behaviour in Service Industries: An Exploratory Study, Journal of Marketing, Vol. 50, No. 2, 1995. https://doi.org/10.2307/ 1252074

[20] Pursetyaningsih, The Influence of Price, Reputation, Service Quality, Promotion, Force Transfer, and Recommendations on Customer Behavior Switching Banks, Jurnal Manajemen Teori dan Terapan, Vol. 1, No. 3, 2008. http://dx.doi.org/ 10.20473/jmtt.v1i3.2371

[21] Abduh, M., Kassim, S., and Dahari, Z., Customer Satisfaction and Switching Behavior in Islamic Banking: Evidence from Indonesia. School of Doctoral Studies (European Union) Journal, Vol. 4, 2012, pp. 209-215. http://irep.iium.edu.my/ id/eprint/26365

[22] Romadhon, G., Analysis of Factors Affecting Customer Switching Behavior, Jurnal Manajemen dan Akuntansi, Vol. 2, No. 3, 2013. $\quad$ https://media.neliti.com/media/ publications/110977-ID-analisis-faktor-faktoryang-memengaruhi.pdf

[23] Sudarsono, H., Tumewang, Y.K., and Kholid, M.N., Customer Adoption of Islamic Banking Services: Empirical Evidence from Indonesia, Journal of Asian Finance, Economics and 
Business, Vol. 8, No. 3, 2021, pp. 1193-1204. https://doi.org/10.13106/jafeb.2021.vol8.no3.1 193

[24] Ryandono, M.N.H, Kusuma, K.A., Prasetyo, A., The Foundation of a Fair Mudarabah Profit Sharing Ratio: A Case Study of Islamic Banks in Indonesia, Journal of Asian Finance, Economics and Business, Vol. 8, No. 4, 2021, pp. 0329-0337. https://doi.org/10.13106/jafeb. 2021.vol8.no4.0329

[25] Samarwan, U., Consumer Behavior. Theory and Its Application in Marketing, Bogor: Ghalia Indonesia, 2004.

[26] Batra, R., Ahuvia, A., \& Bagozzi, P.R., Brand Love, Journal of Marketing, Vol. 76, No. 2, 2012, pp. 1-16. https://doi.org/10.1509\%2Fjm. 09.0339

[27] Colgate, M. and Hedge, R., An Investigation Into The Switching Process In Retail Banking Services, International Journal of Bank Marketing, Vol. 19, No. 5, 2001, pp. 201-212. https://doi.org/ 10.1108/02652320110400888

[28] Subramaniam, R. \& Ramachandran, J., Customers' Switching Behavior in Banking Industry-Empirical Evidence From Malaysia, International Journal of Business, Economics and Law, Vol. 1, 2012, pp. 156-162. http://ijbel.com/wpcontent/uploads/2014/06/Customers $\%$ E2\%80\% 99-Switching-Behavior-In-Banking-IndustryEmpirical-Evidence-From-Malaysia-DrRamaiyer-Subramaniam-Dr-JayalakshmyRamachandran.pdf

[29] Faisol, S., Qualitative Research Formats: Basics And Applications, Jakarta: Rajawali Press, 1995.

[30] Arikunto, S., Research Procedure A Practical Approach, Jakarta: Rineka Cipta, 2006.

[31] Lincoln, Y.S. \& Denzin, N.K., Handbook Qualitative Research, Diterjemahkan Oleh Dariyatno, Badrus Samsu Fata, Abi, John Rinaldi, Cet. 1, Yogyakarta: Pustaka Pelajar, 2009.

[32] Sugiyono, S., Understanding Qualitative Research, Jakarta: Bumi Aksara, 2012.

[33] Drost, E.A., Validity and Reliability in Social Science Research, Education Research and Perspectives, Vol. 38, No. 1, 2011, pp. $105-$ 123. https://www3.nd.edu/ ggoertz/sgameth/ Drost2011.pdf

[34] Baehaki, F., Nahadi, and Firman, H., Development of Reasoning Based Multiple Choice Test to Measure Mastery of Chemical Equilibrium Material, Seminar Nasional Kimia dan Pendidikan Kimia IX (SNKPK IX), Solo : Universitas Sebelas Maret, 2017.

[35] Firman, H., Assessment of Learning Outcomes in Teaching Chemistry, Bandung: PMIPA UPI, 2000.

[36] Fariz, N.M., Mohammed, N.F., Zulkepli, N.S., and Kamaluddin, A., Accounting Conservatism And Financial Performance: Accountability Of Shariah Compliant Companies In Malaysia, Humanities and Social Sciences Letters, Vol. 8, No. 3, 2020, pp. 280-297. https://www/doi.org/ 10.18488/journal.73.2020.83.280.297

[37] Jaya, L., Factors Affecting Customer Switching Behavior in the Retail Banking Industry at Bank BCA, Jurnal Bisnis dan Manajemen, Vol. 52, No. 11, 2016, pp. 115-141. https://journal.untar.ac.id/index.php/bm/article/ view/724/614

[38] Meshref, H., Predicting Loan Approval of Bank Direct Marketing Data Using Ensemble Machine Learning Algorithms, International Journal of Circuits, Systems and Signal Processing, Vol. 14, 2020, pp. 914-922. https://www.naun.org/main/NAUN/circuitssyst emssignal/2020/c382005-daz.pdf

[39] Bao, G., Zeng, F., and Wang, M., Study on Human Resource Allocation Efficiency Based on DEA Analysis, International Journal of Circuits, Systems and Signal Processing, Vol. 14, 2020, pp. 826-832. https://www.naun.org/main/NAUN/circuitssyst emssignal/2020/c182005-dap.pdf

\section{Contribution of Individual Authors to the Creation of a Scientific Article (Ghostwriting Policy)}

Hermanita has done research design, technical implementation, and data processing.

Suci Hayati contributes to the process of data collection and statistical data processing.

\section{Creative Commons Attribution License 4.0 (Attribution 4.0 International, CC BY 4.0)}

This article is published under the terms of the Creative Commons Attribution License 4.0 https://creativecommons.org/licenses/by/4.0/deed.en US 